\title{
The Utilization of Instagram as Moderating Variable between Geography Learning Outcomes and Disaster Preparedness
}

\author{
Ramdan Afrian1, Faiz Urfan'2, Zukya Rona Islami ${ }^{3}$ \\ ${ }^{1}$ ramdan.afrian geo@unsam.ac.id \\ 1, 2,3Pendidikan Geografi, Universitas Samudera
}

Submitted

April 4, 2020
Revised

June 23, 2020

https://dx.doi.org/ 10.17509/jpis.v29i1.24249
Accepted

June 23,2020

\begin{abstract}
This study aims to analyze the use of Instagram as a moderating variable between Geography learning outcomes and disaster preparedness in high school level students. The study conducted in Langsa City, Aceh Province, with a sample of research from public high school's students in Langsa City. The sample selection technique is random purposive sampling. The Data analyzed by linear regression test with moderating variables using IBM SPSS 22. The results showed that the use of Instagram did not increase the impact of learning outcomes on disaster preparedness. This is evidenced by the significance value of the variable use of Instagram by 0.231 which is greater than 0.05 . However, Geography learning outcomes variable has a large influence on disaster preparedness ( $p$ value $=0.00$ and adjusted $R 2=0.660=66 \%$ ). The recommendation of this study is the utilization of Instagram needs to be studied in order to help students learn more optimally in Geography subject.
\end{abstract}

Keywords: Instagram, Geography Learning Outcome, Disaster Preparedness.

\begin{abstract}
ABSTRAK
Penelitian ini bertujuan untuk menganalisis penggunaan Instagram sebagai variabel pemoderasi antara hasil belajar Geografi dan kesiapsiagaan bencana pada siswa sekolah menengah. Penelitian dilakukan di Kota Langsa, Provinsi Aceh, dengan sampel penelitian dari siswa sekolah menengah negeri di Kota Langsa. Teknik pemilihan sampel adalah random purposive sampling. Data dianalisis dengan uji regresi linier dengan variabel moderasi menggunakan IBM SPSS 22. Hasilnya menunjukkan bahwa penggunaan Instagram tidak meningkatkan dampak hasil belajar pada kesiapsiagaan bencana. Ini dibuktikan dengan nilai signifikansi variabel penggunaan Instagram sebesar 0,231 yang lebih besar dari 0,05. Namun, variabel hasil belajar geografi memiliki pengaruh besar pada kesiapan bencana (nilai $p=0,00$ dan R2 yang disesuaikan $=0,660=66 \%$ ). Rekomendasi penelitian ini adalah bahwa penggunaan Instagram perlu dipelajari untuk membantu siswa belajar lebih optimal dalam mata pelajaran Geografi.
\end{abstract}

Keywords: Instagram, Hasil Belajar Geografi, Kesiapan Bencana.

\section{INTRODUCTION}

The use of technology in the internet has greatly increased. This is also supported by the increasing level of community ownership of devices such as smartphones and laptops [1]. An indicator that can illustrate the phenomena is the number of downloads of social media applications on the Google Play Store and App Store. 
Famous applications such as Whatsapp, Facebook and Instagram have reached tens of millions of downloads worldwide. Certainly, this condition has many impacts on the social life of the community. One of the most visible impacts is the pattern of community communication which was initially bilateral to multilateral [2].

The intensity information flow has increased even more significantly among the community. Communities more easily access information about the latest events, so that their information literacy is higher [3]. High school students are part of the community who affected by the development of these technologies. Many high school students are already familiar with social media applications, especially students in urban areas [4]. The use of social media allows students to keep abreast of information from various fields of life, such as technology, fashion, entertainment, or even disaster information.

Currently, the use of social media among students needs to get greater attention from researchers in the field of education. Unconsciously, the use of social media has gradually changed the structure of people's social lives. Students who are accustomed to using social media have better skills in finding and choosing the right information [4]. In addition, they can assess the truth of the information so that they can respond appropriately to the information.

Instagram is one of the most popular social media applications among high school students. In a survey by an institution called "We are Social", Instagram ranked third highest as the most commonly used social media by Indonesians, with an average duration of use of 3 hours 23 minutes per day [5].
Instagram gives a big impact on the change of mindset of high school students through the presentation of a very large and varied amount of content. Instagram is a social media based on sharing photos and videos that makes people willing to use it in high intensity and duration [6]. Hence, the high use of Instagram can have a great influence on high school students.

Social media is an application that is easy to use and has a positive impact on information literacy and disaster preparedness [7]. In the disaster mitigation, the use of Instagram also has an important role because information can affect students' disaster preparedness. However, only certain information can increase disaster preparedness. Consequently, high school students need to be guided in accessing the information they consume from their parents and teachers. Learners' skills in searching and selecting information are the initial capital in the use of social media in the context of classroom learning [3].

Schools are institutions that have a main role in the enhancement of student preparedness [8]. Efforts to improve preparedness can be done through various school programs both intracuricular and extracurricular. Geography is a subject that presents disaster mitigation material at the high school level. That means, Geography subjects have an influence on increasing disaster preparedness of students.

Learning Geography and using Instagram are two combinations that have the potential to increase disaster preparedness because it can improve students' disaster information literacy. Disaster management is not a partial activity, but needs to be done in a structured manner and linked to national development [9], [10]. Through 
Geography learning, students understand the symptoms and the spread of disasters. While through Instagram, students receive the latest disaster information.

Langsa City is one of the cities that located at the east coast of Aceh Province, Indonesia. The city is located near to the North Sumatra Province, so the population mobility is relatively high and experiences a lot of cultural acculturation from outside Aceh. This condition has an impact on the sociocultural dynamics that make the community open-minded and easy to receive new information. Naturally, this condition has an impact on the disaster preparedness of its community. However, this allegation needs to be further investigated so that it can be scientifically proven. Therefore, these argumentations have encouraged researchers to write a research article entitled "The Utilization of Instagram as a Moderating Variable between Geography Learning Outcomes and Disaster Preparedness".

\section{Geography Learning through Instragram}

Social media is a virtual media for exchanging information between individuals in the context of society. Everyone free to share any information with anyone. Information sharing settings can be limited or open. In early 2020, the number of Instagarm application downloads on Google Play was 97 million and 16 million for the App Store. This number is a very high number for an application. This figure shows that Instagram is one of the most popular social media in the world with very many users. Its features are very complete and do not limit the number of photos and videos uploaded by users. Learning involving online applications such as
Instagram gives students better accessibility to subject materials [4].

Several studies have scientifically proven that social media can be used to improve student learning outcome. The use of social media can increase the literacy of information needed to adapt to the dynamic conditions of society [7]. Students become more sensitive to conditions in the surrounding environment, including potential disasters. Then, Marlyono and Pasya was declared to be more specific, namely literacy of information effect significantly by $45 \%$ against the disaster preparedness community [11].

Disaster risk reduction efforts always start from educational institutions, such as school and university through the integration of learning materials in the classroom [8], [12], [13]. One of the objectives of the disaster preparedness school is to build a culture of safety and disaster resilience among school residents, especially for schools located in disaster prone areas [14], [15], [16]. Learning activities can contribute to enhancing students' disaster preparedness so the teacher's role is very important to achieve these goals. Geography teacher is one of the parties related to the problem of disaster. Geography teachers need some additional skills related to disaster preparedness, namely (1) survey skills; (2) disaster monitoring; (3) mapping; (4) counseling; (5) evacuation [17]. Determination of learning methods determines students' study habits, so teacher competence contributes to student learning outcome [18], [19]. Geography learning in the class does not only emphasize the thought process but also the aspects of action so that students are able to apply the learning material that they have understand [20]. To measure the achievement of these 
objectives, the teacher needs an assessment instrument. The preparation of assessment instruments must pay attention to four important components, namely (1) the object of assessment; (2) assessment criteria; (3) assessment results data; and (4) reference considerations [21]. If the implementation of Geography learning is carried out well, it can be predicted that the disaster preparedness of students will be higher.

\section{Disaster Preparedness and Instagram}

Basically, increasing disaster preparedness needs to be planned and measured well. Disaster preparedness is a series of planned and organized activities to reduce fatalities and material losses from a disaster [22], [23], [24]. Improving disaster preparedness for students is a pro-active effort in supporting community resilience to disasters [25], [26]. One effective step that can be taken is to reduce community vulnerability due to low information literacy.

Community vulnerability to disasters can be detected early through Social Media Analytic Tools (SMAT) applications such as Instagram Insight, Meltwater, and Mediatoolkit [27]. Utilization of data on Instagram can use through data mining techniques. Through data mining, social media can be used as a source of data to obtain brief and actual disaster information to reduce disaster risk in a community [1], [28], [29].

Instagram feature that is often used in data mining to find certain information is hashtag. The use of hashtags makes searching more targeted. In addition, the geotagged/geolocation feature on Instagram can also be used as information to detect disaster locations accurately [30]. The geotagged/geolocation feature is very important to map the location of users who have shared disaster information. Geotagged/geolocation analysis on Instagram features is a more effective tool in mapping disaster information in a region [6].

The core component of disaster preparedness is knowledge and awareness of disaster risks and access to information about disasters [22], [31]. The use of appropriate learning media will affect the information received by students. Teachers need to consider using Instagram for learning activities to improve student preparedness, because the process of disaster occurrence needs to be visualized so that students' disaster awareness can increase significantly [32], [33].

\section{RESEARCH METHOD}

This research is a survey research with quantitative approach. Research location in Langsa City, Aceh Province, Indonesia. The variables studied were Geography learning outcomes (variable $\mathrm{X}$ /independent variable), disaster preparedness (variable $\mathrm{Y} /$ dependent variable) and Instagram utilization (variable $\mathrm{M} /$ moderation variable). The research population is high school students in Langsa City, Aceh Province, Indonesia. The research sample was selected using random purposive sampling in five public high schools in Langsa City. The students who became the study sample were class XII social science program. Students of class XII social science have received almost all the material in Geography subjects so that they are selected as research samples. The composition of the research sample can be seen in table 1. 
value $=0,000$ for the Geography learning outcome variable. This figure shows that the learning outcome some vital lessons of Geography has a variable effect on emergency preparedness. The following is the regression equation.

Table 2. Model Summary

\begin{tabular}{ccccc}
\hline Model & R & R Square & Adjusted R Square & Std. Error of the Estimate \\
\hline 1 & $0,814^{\mathrm{a}}$ & 0,662 & 0,660 & 9,533 \\
\hline
\end{tabular}

a. Predictors: (Constant), Geography Learning Outcome

Table 3. ANOVA ${ }^{a}$

\begin{tabular}{ccccccc}
\hline & Model & Sum of Squares & df & Mean Square & F & Sig. \\
\hline \multirow{3}{*}{1} & Regression & 24402,655 & 1 & 24402,655 & 268,517 & $0,000^{b}$ \\
\cline { 2 - 7 } & Residual & 12450,467 & 137 & 90,879 & & \\
\cline { 2 - 7 } & Total & 36853,122 & 138 & & & \\
\hline
\end{tabular}

a. Dependent Variable: Disaster Preparedness

b. Predictors: (Constant), Geography Learning Outcome

Table 4. Coefficients ${ }^{\mathrm{a}}$

\begin{tabular}{|c|c|c|c|c|c|c|}
\hline & \multirow[t]{2}{*}{ Model } & \multicolumn{2}{|c|}{ Unstandardized Coefficients } & \multirow{2}{*}{$\begin{array}{c}\begin{array}{c}\text { Standardized } \\
\text { Coefficients }\end{array} \\
\text { Beta } \\
\end{array}$} & \multirow[t]{2}{*}{$\mathbf{t}$} & \multirow[t]{2}{*}{ Sig. } \\
\hline & & B & Std. Error & & & \\
\hline \multirow[b]{2}{*}{1} & (Constant) & 4,668 & 2,524 & & 1,849 & 0,067 \\
\hline & $\begin{array}{c}\text { Geography Learning } \\
\text { Outcome }\end{array}$ & 2,952 & 0,180 & 0,814 & 16,386 & 0,000 \\
\hline
\end{tabular}

a. Dependent Variable: Disaster Preparedness

\section{Instagram Utilization Variable Test Results}

Table 5 presents the results of the regression analysis between variable $M$ and variable $Y$. In table 5 , it can be seen the adjusted $R 2$ value is 0,007 . The number shows that the Instagram utilization does not determine disaster preparedness. Then in table 6 can be seen the significance value of $p$-value $=0,985$ (both F-test and t-test) which is greater than 0,05 . This means that the variable usage of
Instagram has no effect at all on the disaster preparedness variable. Based on table 5 and table 6 it can be concluded that the variable use of Instagram is completely unrelated to disaster preparedness. Therefore, unstandardized and standardized equations from the results of this analysis need not be considered. However, if needed, the results of the analysis of coefficients in this equation can be seen in table 7 .

Table 5. Model Summary

\begin{tabular}{ccccc}
\hline Model & $\mathbf{R}$ & R Square & Adjusted R Square & Std. Error of the Estimate \\
\hline 1 & $0,002^{\mathrm{a}}$ & 0,000 & $-0,007$ & 16,401 \\
\hline
\end{tabular}

a. Predictors: (Constant), Instagram Utilization

Table 6. ANOVA ${ }^{a}$

\begin{tabular}{ccccccc}
\hline & Model & Sum of Squares & df & Mean Square & F & Sig. \\
\hline \multirow{4}{*}{1} & Regression & 0,101 & 1 & 0,101 & 0,000 & $0,985^{\mathrm{b}}$ \\
\cline { 2 - 7 } & Residual & 36853,021 & 137 & 269,000 & & \\
\cline { 2 - 7 } & Total & 36853,122 & 138 & & & \\
\hline
\end{tabular}

a. Dependent Variable: Disaster Preparedness

b. Predictors: (Constant), Instagram Utilization

6 Ramdan Afrian, et al | The Utilization of Insta.... 
Table 7. Coefficients ${ }^{a}$

\begin{tabular}{ccccccc}
\hline \multirow{2}{*}{ Model } & \multicolumn{2}{c}{ Unstandardized Coefficients } & $\begin{array}{c}\text { Standardized } \\
\text { Coefficients }\end{array}$ & t & Sig. \\
\cline { 2 - 5 } & & B & Std. Error & Beta & & \\
\hline \multirow{2}{*}{1} & (Constant) & 43,785 & 3,909 & & 11,200 & 0,000 \\
\cline { 2 - 5 } & Instagram Utilization & 0,002 & 0,081 & 0,002 & 0,019 & 0,985 \\
\hline
\end{tabular}

a. Dependent Variable: Disaster Preparedness

\section{Result of Moderating Regression Analysis}

Table 8 presents the results of the regression analysis between variable $X$ and variable $Y$ along with variable $M$. In table 8 , we can see the adjusted $R 2$ value of 0,659 . This number shows that disaster preparedness is determined by the learning outcomes of Geography and the use of Instagram as a moderating variable of $65,9 \%$, while $33,1 \%$ is determined by other variables not examined in this study. Then in table 9 can be seen the significance value of $p$ value $=0,000$ (F-test) which is smaller than 0,05 . This means that the
Geography learning outcomes variable moderated by the use of Instagram has been proven empirically to influence the disaster preparedness variable. In table 10 , it can be concluded that the unstandardized and standardized equations between $X$ and $Y$ variables by looking at the columns of unstandardized coefficients and standardized coefficients. The following is the regression equation.

- Unstandardized Regression

$Y=-3,373+3,440 X+0,172 M-0,010 X M$

- Standardized Regression $Y=0,948 X+0,181 M-0,194 X M$

Table 8. Model Summary

\begin{tabular}{ccccc}
\hline Model & $\mathbf{R}$ & R Square & Adjusted R Square & Std. Error of the Estimate \\
\hline 1 & $0,816^{a}$ & 0,666 & 0,659 & 9,545
\end{tabular}

a. Predictors: (Constant), Moderating Variable, Geography Learning Outcome, Instagram Utilization

Table 9. ANOVA ${ }^{a}$

\begin{tabular}{|c|c|c|c|c|c|c|}
\hline & Model & Sum of Squares & $\mathrm{df}$ & Mean Square & $\mathrm{F}$ & Sig. \\
\hline \multirow{3}{*}{1} & Regression & 24554,200 & 3 & 8184,733 & 89,840 & $0,000^{b}$ \\
\hline & Residual & 12298,922 & 135 & 91,103 & & \\
\hline & Total & 36853,122 & 138 & & & \\
\hline
\end{tabular}

a. Dependent Variable: Disaster Preparedness

b. Predictors: (Constant), Moderating Variable, Geography Learning Outcome, Instagram Utilization

Table 10. Coefficients ${ }^{a}$

\begin{tabular}{|c|c|c|c|c|c|c|}
\hline & \multirow[t]{2}{*}{ Model } & \multicolumn{2}{|c|}{$\begin{array}{l}\text { Unstandardized } \\
\text { Coefficients }\end{array}$} & \multirow{2}{*}{$\begin{array}{c}\text { Standardized } \\
\text { Coefficients } \\
\text { Beta } \\
\end{array}$} & \multirow[t]{2}{*}{$t$} & \multirow[t]{2}{*}{ Sig. } \\
\hline & & B & Std. Error & & & \\
\hline \multirow{4}{*}{1} & (Constant) & $-3,373$ & 7,136 & & $-0,473$ & 0,637 \\
\hline & $\begin{array}{l}\text { Geography Learning } \\
\text { Outcome }\end{array}$ & 3,440 & 0,523 & 0,948 & 6,582 & 0,000 \\
\hline & Instagram Utilization & 0,172 & 0,143 & 0,181 & 1,202 & 0,231 \\
\hline & Moderating Variable & $-0,010$ & 0,011 & $-0,194$ & $-0,980$ & 0,329 \\
\hline
\end{tabular}

a. Dependent Variable: Disaster Preparedness 
Based on the results of data analysis, it can be concluded that the use of Instagram does not significantly impact disaster preparedness, neither as an independent variable nor as a moderating variable. However, the learning outcomes of Geography significantly affect disaster preparedness at $65,9 \%$ (adjusted $R^{2}=$ $0,659)$. An overview of the analysis from table 10 can be seen in Figure 2 .

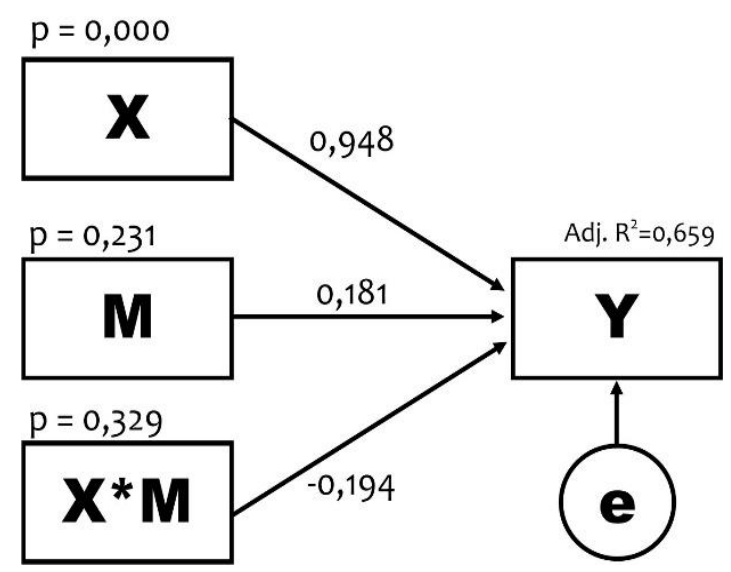

Figure 2. Result of Moderating Regression Analysis.

Figure 2 explains the results of moderating regression analysis with some numerical information on each variable. Each variable has a different $t$ test result. Geography learning outcomes (variabel $X$ ) have the results of $t$-test with a value of $p$-value $=0,000$ ( $p$-value<0,05) which indicates the results of Geography lessons have a significant effect on disaster preparedness (variable $\mathrm{Y}$ ). While the utilization of Instagram (variable $M$ as the independent variable and the variable $X * M$ as a moderating variable) has a value of $\mathrm{p}$-value greater than 0,05 ( $p$-value $=0,231$ and $p$-value $=0,329)$ so that the use of Instagram can not act as the independent variable and as a variable moderation on the model.

Then, in Figure 2 also shown the coefficient value of each variable, which is 0,$948 ; 0,181$; and $-0,194$. As can be seen, Geography learning outcomes have the greatest coefficient. This is relevant to the previously $\mathrm{p}$-value so that Geography learning outcomes have been statistically proven to have a significant influence with a large contribution. As for the use of Instagram (variable $M$ and variable $X * M$ ) has smaller coefficients, namely 0,181 and $-0,194$. This figure is also relevant to the results of the t-test, which does not indicate any significant influence from the use of Instagram, either as an independent variable or as a moderating variable.

This study gives different results compared to previous studies which found that the use of social media can significantly influence the quality of learning. Although such studies do not undermine these theories, but rather as one of the exceptions to such theories. The most important thing in a research is not colliding arguments to choose the most correct research, but looking for an explanation of all the findings that occur in the field. For that reason, the findings in this study need to be analyzed the causes. There are at least three things that cause the variable in the Instagram utilization not to significantly influence in this study.

First, the teacher does not direct students to use Instagram in finding additional material. One indicator of achievement in learning Geography is increasing disaster preparedness in students. Geography teacher has an important role in achieving this. Then, teachers need to realize the great potential behind the existence of Instagram as an application that is often accessed by students. Nowadays, many people have created Instagram accounts and collected information about geography and about disaster. 
This is an opportunity for teachers to enrich students' insights in a fun way.

Second, Instagram accounts that are serious about providing disaster information are still very limited. This makes students have few opportunities to access new information about disasater. This weakness can be overcome through the assignment of Geography teachers in the classroom. The teacher can assign students to draw pictures or look for photos related to disaster data or information. Then the task can be collected in one Instagram account that can be accessed by Instagram users around the world. Thus, accounts that contain disaster information will be more numerous and students' insights will be even broader.

Third, there are no assessment instruments that are compatible with social media-based learning. The assessment instrument will help teachers find out the effectiveness of the use of social media by students. In addition, this assessment instrument serves as an evaluator to improve further learning. The use of Instagram in learning in the classroom is still relatively new. Even some schools still implement restrictions on the use of mobile phones during class learning. This is certainly an obstacle for teachers who use Instagram as a learning media.

\section{CONCLUSION}

The use of Instagram is not proven as a moderating variable even though various literature and research results show the opposite. Social media should be a catalyst in the process of achieving learning goals, including increasing disaster preparedness. Nevertheless, in this study, the Instagram utilization does not have main role in that way. This can be caused by students use Instagram to the extent possible for entertainment and to find other information that is not related to Geography material that is learned at school. On the other hand, Geography learning outcomes have a great impact on increasing disaster preparedness in high school students. This condition is an excellent indicator for the success of Geography learning in schools. If Geography teachers can collaborate the utilization of Instagram with learning materials in class, it can be predicted that learning outcomes for students will increase significantly.

\section{RECOMMENDATION}

This research does not undermine the theories that have been generated from previous studies, namely the use of social media has a positive impact on learning. But this research is an indicator of the development of social media-based learning media that has not been optimal in Public High School at Langsa City. Instagram is an application that has a lot of potential to be developed for the advancement of education because it is in demand by many users who are still in school. Based on the results of the study, researchers proposed recommendations for Geography teachers and other education observers to develop Instagram-based learning media.

\section{REFERENCES}

[1] A. Sutedi, "Rancang Bangun Aplikasi Pengidentifikasi Bencana dan Lokasi Aman Bencana Berbasis Media Sosial," algoritma, vol. 16, no. 2, pp. 239-246, 2020.

[2] Saleh and R. Pitriani, "Pengaruh Media Sosial Instagram dan WhatsApp Terhadap Pembentukan Budaya 'Alone Together,"' J. Komun, vol. 10, no. 
2, p. 103, 2018.

[3] H. Lai and T. Tang, "From Information Behaviors to Disaster Preparedness: Navigating Individuals' General and Disaster Curation in U.S., China, and Australia," Comput. Human Behav., vol. 88, pp. 37-46, 2018.

[4] and N. J. T. Najafi Ghezeljeh, J. Mohammad Aliha, H. Haghani, "Effect of Education Using The Virtual Social Network on The Knowledge and Attitude of Emergency Nurses of Disaster Preparedness: A QuasiExperiment Study," Nurse Educ. Today, vol. 73, pp. 88-93, 2019.

[5] H. Helen and F. Rusdi, "Pengaruh Penggunaan Media Sosial Akun Instagram @Jktinfo Terhadap Pemenuhan Kebutuhan Informasi Followers," J. Prologia, vol. 2, no. 2, p. 355, 2019.

[6] and M. B. K. D. R. Domínguez, R. P. Díaz Redondo, A. F. Vilas, "Sensing the City With Instagram: Clustering Geolocated Data for Outlier Detection," Expert Syst. Appl., vol. 78, pp. 319-333, 2017.

[7] and S. F. W. J. K. Kavota, J. R. K. Kamdjoug, "Social Media and Disaster Management: Case of The North and South Kivu Regions in The Democratic Republic of The Congo," ternational J. Inf. Manag., vol. 52, p. 102068, 2020.

[8] Q. Umam and F. Rahman, "SENA SAKTI (Sekolah Bencana; Siaga, Aksi dan Mitigasi)," JIIS, vol. 4, no. 1, 2018.

[9] and A. A. U. Hariadi, S. Suratman, T. Gunawan, "Kearifan Lokal Komunitas Sebagai Modal Sosial alam Manajemen Bencana Alam," MGl, vol. 33, no. 2, 2020.

[10] L. Honesti and N. Djali,
"Pendidikan Kebencanaan di Sekolah - Sekolah di Indonesia Berdasarkan Beberapa Sudut Pandang Disiplin IImu Pengetahuan," J. Momentum, vol. 12, no. 1, pp. 51-56, 2012.

[11] S. G. Marlyono and G. K. Pasya, "Peranan Literasi Informasi Bencana terhadap Kesiapsiagaan Bencana Masyarakat Jawa Barat," J. Geogr. Gea, vol. 8, 2016.

[12] H. Baytiyeh and M. K. Naja, "Revolutionising Engineering Education in The Middle East Region to Promote EarthquakeDisaster Mitigation," Eur. J. Eng. Educ., vol. 39, no. 5, pp. 573-583, 2014.

[13] M. Desfandi, "Urgensi Kurikulum Pendidikan Kebencanaan Berbasis Kearifan Lokal di Indonesia [The urgency of disaster education curriculum based on local wisdom in Indonesia\}," Sosio Didakt. Sos. Sci. Educ. J., vol. 1, no. 2, 2014.

[14] A. Sakurai et al., "Exploring Minimum Essentials for Sustainable School Disaster Preparedness: A Case of Elementary Schools in Banda Aceh City, Indonesia," Int. J. Disaster Risk Reduct., vol. 29, pp. 73-83, 2018.

[15] D. A. N. Konfirmasi, E. E. K. Serta, K. Sebagai, B. Ajar, M. Pelajaran, and G. Sma, "Edu Geography," vol. 1, no. 2, pp. 1-5, 2013.

[16] A. Rusilowati and A. Widiyatmoko, "Pembelajaran Kebencanaan Alam Bervisi Sets Terintegrasi Dalam Mata Pelajaran Fisika Berbasis Kearifan Lokal," J. Pendidik. Fis. Indones., vol. 11, no. 1, pp. 42-48, 2015.

[17] S. Susilawati, "Peranan Guru Geografi dalam Mitigasi Bencana 
Longsor Lahan," J. Pendidik. Geogr., vol. 7, no. 1, 2016.

[18] and B. B. F. Rosyida, S. Utaya, "Pengaruh Kebiasaan Belajar dan Self-Efficacy terhadap Hasil Belajar Geografi Di SMA," JPG, vol. 21, no. 1, 2016.

[19] and I. S. S. T. K. Sakti, N. Hairunisya, "Pengaruh Kompetensi Pedagogik Guru dan Gaya Belajar Siswa Terhadap Prestasi Belajar Siswa Pada Mata Pelajaran IPS," JPIS, J. Pendidik. Ilmu Sos, vol. 28, no. 1, p. 53, 2019.

[20] and G. K. P. A. Novarita, D. Sugandi, "Peranan Pembelajaran Geografi dalam Pembentukan Sikap Peserta Didik terhadap Mitigasi Bencana Gempa Bumi dan Longsor di Kota Padang," J. Pendidik. Geogr., vol. 15, no. 1, 2016.

[21] L. Wahyuni and M. Ruhimat, "Pengembangan Model Penilaian Projek untuk Mengukur Aspek Psikomotor pada Mata Pelajaran Geografi," JPIS, J. Pendidik. IImu Sos, vol. 27, p. 11, 2018.

[22] Handriyana and S. Cholid, "Peran Forum Pengurangan Resiko Bencana Desa Pasawahan Kabupaten Garut dalam Kesiapsiagaan Bencana," JIKS, vol. 18, no. 1, 2017.

[23] S. Veronica and S.P Honggowidjaja, "GEMPA: Game Edukasi sebagai Media Sosialisasi Mitigasi Bencana Gempa Bumi bagi Anak Autis," J. Pendidik. dan Pembelajaran Univ. Negeri Malang, vol. 6, no. 1, pp. 115-120, 2013.

[24] C. A. Paramesti, "Kesiapsiagaan Masyarakat Kawasan Teluk Pelabuhan Ratu Terhadap Bencana Gempa Bumi dan Tsunami," J. Reg. City Plan., vol. 22, no. 2, p. 113, 2011.
[25] S. Haryuni, "Pengaruh Pelatihan Siaga Bencana Gempa Bumi Terhadap Kesiapsiagaan Anak Usia Sekolah Dasar Dalam Menghadapi Bencana Gempa Bumi Di Yayasan Hidayatul Mubtadiin Kediri," JIK, vol. 6, no. 2, p. 133, 2018.

[26] D. Kurniawati and S. Suwito, "Pengaruh Pengetahuan Kebencanaan terhadap Sikap Kesiapsiagaan dalam Menghadapi Bencana pada Mahasiswa Program Studi Pendidikan Geografi Universitas Kanjuruhan Malang," JPIG, vol. 2, no. 2, 2019.

[27] and K. M. S. Anson, H. Watson, K. Wadhwa, "Analysing Social Media Data for Disaster Preparedness: Understanding the Opportunities and Barriers Faced by Humanitarian Actors," Int. J. Disaster Risk Reduct., vol. 21, pp. 131-139, 2017.

[28] and P. M. Edi Puspito, Sumardjo Sumardjo, Titik Sumarti, "Perilaku Komunikasi Perempuan dan LakiLaki di Wilayah Rawan Bencana Gunung Api," Mimb. J. Sos. dan Pembang., vol. 30, no. 1, pp. 72-82, 2014.

[29] and C. T. E. Z. Li, Q. Huang, "Introduction to Social Sensing and Big Data Computing for Disaster Management," Int. J. Digit. Earth, vol. 12, no. 11, pp. 1198-1204, 2019.

[30] and H. N. X. Huang, Z. Li, C. Wang, "Identifying Disaster Related Social Media for Rapid Response: A Visual-Textual Fused CNN Architecture," Int. J. Digit. Earth, pp. 1-23, 2019.

[31] R. Rahmad, "Penilaian Kerentanan dan Kesiapsiagaan Bencana Tsunami di Pesisir 
Sadeng, Gunungkidul," JPIS, J. Pendidik. Ilmu Sos, vol. 11, no. 2, 2019.

[32] Social Education on Earth Quake and Tsunami Disaster in West
Sumatera, "Markolinda," Mimb. J. Sos. dan Pembang., p. 10, 2016.

[33] A. M. Haifani, "Manajemen resiko bencana gempa bumi," Semin. Nas. IV, pp. 25-26, 2008. 